\title{
EFEKTIFITAS SWEDISH MASSAGE TERHADAP TINGKAT NYERI DAN TEKANAN DARAH PASIEN PASCA BEDAH JANTUNG
}

\author{
Ai Cahyati \\ Program Studi DIV Keperawatan Poltekkes Kemenkes Tasikmalaya \\ email : ai.cahyati94@gmail.com
}

\begin{abstract}
ABSTRAK
Nyeri pasca bedah jantung disebabkan oleh multifaktor. Tindakan operasi memberikan manipulasi pada lapisan otot, syaraf dinding dada akibat dilakukannya sternotomy. Nyeri paska $C A B G$ dapat diakibatkan cidera saraf intercostadindi ng dada akibat pembedahan pada sisi sternotomy, adanya drain di dada, tirah baring yang lama yang menimbulkan sakit dan menyebabkan pasien susah bernafas, batuk dan tidur. Massage merupakan salah satu terapi komplementer non farmakologi yang dapat mengurangi rasa nyeri pasien paska bedah jantung. Evidence Based Nursing Practice (EBNP) menilai efektifitas Swedish massage untuk menurunkan tingkat nyeri, tekanan darah pada pasien pasca bedah jantung. Analisis bivariat yang digunakan adalah uji t dependen (paired t-test) dan uji t independen. Subjek penelitian 10 orang. Kelompok kontrol hanya mendapat relaksasi saja sedangkan kelompok intervensi mendapat perlakuan relaksasi dan Swedish massage. Hasil pelaksanaan EBNP menunjukkan bahwa Swedish massage efektif secara signifikan menurunkan tingkat nyeri pasien, tekanan darah kelompok intervensi ( $p$ value $<0,05$ ). Pada kelompok kontrol yang mendapat relaksasi saja menunjukan hubungan yang signifikan terhadap penurunan tingkat nyeri pasien. Saran: Swedish Massage sebaiknya dijadikan sebagai salah satu intervensi keperawatan. Perlu dilakukan penelian lebih lanjut tentang Swedish Massage dikombinasikan dengan terapi lainnya dan dipertimbangkan untuk penambahan sample penelitian pada penelitian selanjutnya.
\end{abstract}

\section{Kata Kunci: Swedish Massage, Nyeri, Tekanan Darah, Pasca Bedah Jantung}

\begin{abstract}
Pain post heart surgery caused by multi factors. The surgery gives manipulation on the tissues of muscles, nerve on the chest walls as the result of sternotomy. Pain after CABG can be caused by the injury of intercosta nerves on the chest walls including on the breathing muscles as the result of the surgery on the side of sternotomy, the availability of drain in the chest, the long laying can cause pain on the neck, shoulder and back which cause patient difficult to take a breath, coughts and sleep. Massage is one of the complementary non phamacology theraphiest which can reduce the pain of patient post heart surgery. Swedish massage decreases the patient's pain, bood pressure post heart surgery. Bivariat Analysis which is used in EBNP was Paired t-test and t independent test. The subject was 10 persons. The control group got the relaxation only, whereas, the intervention group got relaxation and Swedish massage. The result of EBNP implementation showed that Massage was effective significantly to decrease patient's pain level, blood preasure on the intervention group ( $p$ value $<0,05)$. On the control group which relaxation only showed the significant correlation on the decreasing patient's pain level. Advice: Swedish massage should be one of intervention in case patient with cardiovascular desease, it is necessary to concuct further research on the effectiveness of Swedish massagewich is combined with other therapies, and also considered the addition of samples of research if want to held the same research.
\end{abstract}

Key Word: Swedish Massage, Pain, Blood Pressure, Post Heart Surgery 


\section{PENDAHULUAN}

Penyakit jantung dapat berupa kelainan anatomis, penyakit arteri koroner, kerusakan katup, neoplasma maupun trauma jantung dapat mengakibatkan gangguan terhadap hemodinamik. Penyakit arteri koroner (Coronary Artery Disease) sering berhubungan dengan pengerasan pada pembuluh darah arteri yang menyebabkan pembuluh darah arteri mengalami penurunan elastisitas,sehingga arteri menjadi tersumbat karena tertutup Jumlah pasien yang mengalami bedah jantung di Rumah Sakit Pusat Jantung Nasional Harapan Kita (RSPJNHK) pada tahun 2012 terdapat 144.820 kunjungan dengan masalah jantung dan pembuluh darah, \pm 2000 kasus diantaranya menjalani pembedahan. Tindakan bedah CABG dan repair atau replace katup paling sering dilakukan pada unit bedah dewasa (Soetisna, 2013).

Tindakan operasi sternotomy memberikan manipulasi pada lapisan otot, syaraf pada dinding dada, iskemia jaringan, spasme otot, trauma pada saraf dapat menyebabkan tekanan atau tarikan pada saraf akan menyebabkan terangsangnya reseptor nyeri yang bersifat mekanosensitif dan menyebabkan nyeri yang hebat. Spasme otot juga meningkatkan kecepatan metabolisme dalam jaringan otot, sehingga memperberat keadaan iskemia dan menyebabkan terjadinya pelepasan bahan kimiawi pemicu timbulnya nyeri (Guyton \& Hall, 2008).Rasa nyeri pada pasien bedah Swedish Massage merupakan salah satu terapi komplementer non farmakologi untuk mengurangi rasa nyeri juga menurunkan tekanan darah pasien paska bedah jantung. Swedish Massage merupakan teknik yang memobilisasi beberapa struktur dari otot dan jaringan subkutan dengan pemberian tekanan mekanik ke dalam jaringan, yang akan meningkatkan darah balik, mengurangi bengkak dan memobilisasi otot dan kulit (Nerbass, Feltrim, Sauza, et all, 2010). Melihat efek samping operasi jantung terhadap hemodinamik pasien, maka penulis tertarik untuk menerapkan Evidence oleh material plak tersebut. Penyumbatan pembuluh darah menyebabkan arteri yang mensuplai darah ke otot jantung (arteri koroner) mengalami gangguan yang mengakibatkan terjadinya iskemik dan nekrosis pada jantung (Ignatavicius \& Workman, 2010). Kelainan anatomi yang biasanya disebabkan oleh kelainan jantung bawaan dapat berupa Transposition Of Great Arteri (TGA), Atrium Septal Defect (VSD), Ventrikel Septal Defect (VSD) dan Tetralogi Fallot.

jantung juga bisa disebabkan oleh adanya drain di dada, waktu tirah baring yang lama yang akan menimbulkan sakit di leher, bahu dan punggung akan menyebabkan pasien susah untuk bernafas, batuk dan tidur (Nerbass, Feltrim, Sauza, et all, 2010).

Nyeri sangat mempengaruhi status hemodinamik pasien, gangguan imun, hiperglikemi dan peningkatan katekolamin, kortisol dandiuretik hormon (Putillo, et al dalam Stites, 2013). Selanjutnya nyeri yang tidak terkontrol dapat berefek pada psikologis, yaitu mengakibatkan depresi, ansietas, delirium, post traumatik stress disorder dan disorientasi (Jacobi, Fraser, Coursin, et al. dalam Stites, 2013).Nyeri apabila tidak ditangani akan meningkatkan aktifitas simpatis, sistem saraf otonom dirangsang dan melepaskan epinefrin yang nantinya akan meningkatkan tekanan darah dan nadi sehingga dapat meningkatkan beban kerja miokardium dan pasokan oksigen ke jantung (Arbour \& Gelinas, 2011).

Based Nursing Practice (EBNP) tentang "Efektifitas Swedish massage terhadap tingkat nyeri dan tekanan darah pasien paska bedah jantung".

\section{METODE PENELITIAN}

Analisa data yang digunakan adalah analisis Univariat: data disajikan untuk menggambarkan masing-masing variabel, yaitu umur, jenis kelamin, tingkat pendidikan, status pernikahan, pekerjaan, diagnose medik, tingkat nyeri, tekanan darah sebelum intervensi dan setelah intervensi. Analisis bivariat yang digunakan 
pada penelitian ini adalah uji $\mathrm{t}$ dependen (paired t-test) untuk menguji perbedaan rata-rata skor tingkat nyeri, tekanan darah sebelum dan sesudah dilakukan intervensi baik pada kelompok kontrol maupun kelompok intervensi, sedangkan uji $t$ independen dilakukan untuk menguji perbedaan rata-rata skor tingkat nyeri, tekanan darah antara kelompok kontrol dengan kelompok intervensi.

Jumlah subjek yang diambil dalam penerapan EBNP ini diambil berdasarkan perhitungan The Number Needed to Treat (NNT), yang dipandang tepat dalam menilai efek dari suatu intervensi (Gouskova, Kundu, \& Imrey, 2010). Diketahui bahwa: proporsi keberhasilan kelompok intervensi $=0,52$ dan proporsi keberhasilan kelompok kontrol=0,38, sehingga jumlah subjek:14. Jumlah subjek dalam penerapan EBNP ini adalah minimal 14 orang, tetapi karena pelaksanaan penerapan EBNP sebelumnya yang dilaksanakan oleh Maulana (2013) berjumlah 20 orang, maka subjek pelaksanaan EBNP ini minimal sama dengan EBNP sebelumnya yaitu 20 orang.

Subyek EBNP penerapan massage adalah pasien paska bedah jantung yang dirawat di ruang IW Bedah dengan kriteria inklusi: bersedia menjadi responden, mendapat terapi parasetamol 3 x $1000 \mathrm{mg}$, pasien CABG atau operasi katup dengan sternotomy medial atau keduanya, hari kedua sampai hari keenam post operasi, pasien sudah terekstubasi, hemodinamik stabil. Sedangkan kriteria ekslusi sampel adalah pasien yang tidak sadar, mengalami perdarahan masive(> 200 cc per jam), tampak laserasi di kulit area yang akan dipijat.
Pelaksanaan EBNP pada kelompok intervensi dimulai dengan mengidentifikasi pasien yang memenuhi kriteria inklusi, lalu menjelaskan pada pasien tentang tujuan, manfaat dan prosedur pelaksanaan EBNP, responden menandatangani informed concent, sebelum tindakan menanyakan skala nyeri pasien dengan Verbal Respon Scale (VRS), mengukur tekanan darah responden, mengatur posisi nyaman pasien yang memungkinkan untuk massage seperti posisi duduk membungkuk dengan memeluk bantal, tidur dengan posisi miring atau duduk dengan kaki menjuntai ke sisi tempat tidur pasien dan perawat berada tepat di belakang pasien, mengusapkan baby oil/vaselin atau yang sejenis pada area target massage secukupnya, melakukan pemijatan pada area otot trapezius dan rhomboid kiri dan kanan, otot deltoid dan bisep kiri dan kanan, otot pectoralis mayor kiri dan kanan, kepala dan dahi, bagi pasien yang tidak ada luka insisi di kaki lakukan pemijitan di kaki. Pemijatan dilakukan selama 15 menit, dilanjurkan reknik relaksasi selama 10 menit. Setelah tindakan dilakukakan evaluasi dengan menanyakan tingkatan nyeri, mengukur tekanan darah setelah tindakan dilakukan.

Pada kelompok kontrol dilakukan identifikasi pasien yang memenuhi kriteria inklusi, menjelaskan pada pasien tentang tujuan, manfaat dan prosedur pelaksanaan EBNP, responden menandatangani informed concent, sebelum tindakan menanyakan skala nyeri pasien dengan VRS, mengukur tekanan darah responden, melakukan teknik relaksasi mengkaji skala nyeri dengan VRS dan mengukur tekanan darah. 


\section{HASIL PENELITIAN}

\section{Karakteristik Responden}

Tabel 1.

Distribusi Frekuensi Responden berdasarkan Karakteristik Jenis Kelamin, Diagnosa Medik di IW Bedah RSJPD Harapan Kita

\begin{tabular}{|c|c|c|c|c|c|c|c|}
\hline \multirow[t]{2}{*}{ No } & \multirow[t]{2}{*}{ Variabel } & \multicolumn{2}{|c|}{$\begin{array}{l}\text { Kellnterven } \\
\text { si }(n=10)\end{array}$} & \multicolumn{2}{|c|}{$\begin{array}{c}\text { Kel } \\
\text { Kontrol } \\
(n=10)\end{array}$} & \multicolumn{2}{|c|}{$\begin{array}{l}\text { Jumlah } \\
(n=20)\end{array}$} \\
\hline & & $f(x)$ & $\%$ & $f(x)$ & $\%$ & $f(x)$ & $\%$ \\
\hline \multirow[t]{3}{*}{1} & JenisKelamin & & & & & & \\
\hline & Perempuan & 4 & 40 & 2 & 20 & 6 & 30 \\
\hline & Laki-laki & 6 & 60 & 8 & 80 & 14 & 60 \\
\hline \multirow[t]{4}{*}{2} & Diagnosa Medik & & & & & & \\
\hline & CABG 3 VD & 6 & 60 & 8 & 80 & 14 & 70 \\
\hline & Katup repair & 3 & 30 & 1 & 10 & 4 & 20 \\
\hline & $\begin{array}{l}\text { Katup } \\
\text { Replacement }\end{array}$ & 1 & 10 & 1 & 10 & 2 & 10 \\
\hline
\end{tabular}

Berdasarkan tabel di atas dapat diketahui bahwa sebagian besar responden pada kelompok intervensi berjenis kelamin lakilaki $(60 \%)$, begitu juga pada kelompok kontrol $(80 \%)$ dan diagnosa medis pada kelompok intervensi sebagian besar adalah post CABG 3 VD (60\%), begitu juga pada kelompok kontrol (80\%).

Tabel 2

Distribusi Responden berdasarkan Umur, Ejection Fraction (EF), Skala Nyeri dan Tekanan Darah Responden di IW Bedah RSJPD Harapan Kita

\begin{tabular}{|c|c|c|c|c|c|}
\hline No & Variabel & Mean & SD & Minimal & Maksimal \\
\hline \multirow[t]{3}{*}{1.} & Umur & & & & \\
\hline & a. Kontrol & 56,6 & 6,36 & 44 & 68 \\
\hline & b. Intervensi & 58,7 & 7,56 & 45 & 68 \\
\hline \multirow[t]{3}{*}{2.} & Ejection Fraction (EF) & & & & \\
\hline & a. Kontrol & 60,4 & 14,99 & 37 & 68 \\
\hline & b. Intervensi & 61,3 & 12,29 & 45 & 76 \\
\hline \multirow[t]{6}{*}{3.} & $\begin{array}{l}\text { Skala Nyeri } \\
\text { a. Kontrol }\end{array}$ & & & & \\
\hline & - Sblm & 5,10 & 0,876 & 4 & 6 \\
\hline & - Sesudah & 4,6 & 1,075 & 3 & 6 \\
\hline & $\begin{array}{l}\text { b. Intervensi } \\
\text { - Sebelum }\end{array}$ & & & & \\
\hline & - Sesudah & 4,5 & 1,179 & 3 & 6 \\
\hline & & 1,6 & 1,578 & 0 & 5 \\
\hline No & Variabel & Mean & SD & Minimal & Maksimal \\
\hline 4. & $\begin{array}{l}\text { Tek. Sistolik } \\
\text { a. Kontrol }\end{array}$ & & & & \\
\hline
\end{tabular}




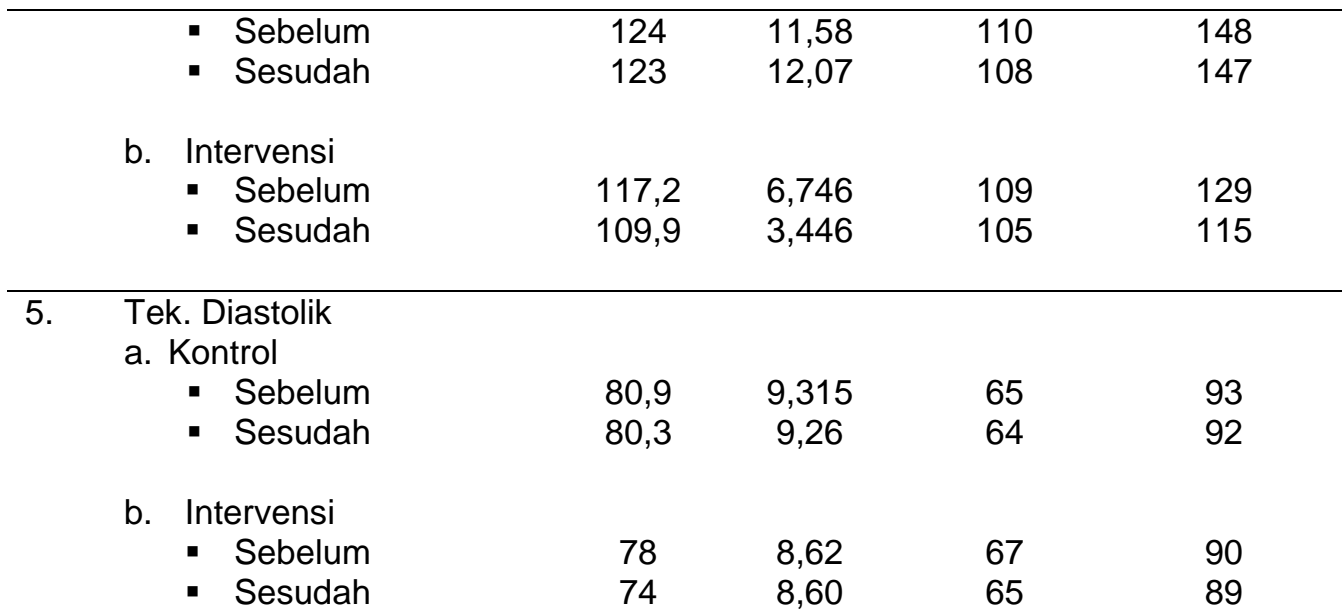

Rata-rata umur renponden berumur 56,6 tahun pada kelompok kontrol dan 58,7 tahun pada kelompok intervensi. Ratarata Ejection Fraction (EF) responden 60,4 pada kelompok kontrol dan 61,3 pada kelompok intervensi. Skala nyeri pada kelompok kontrol mengalami penurunan sebanyak 0,5 poin yaitu dari
5,10 menjadi 4,6, sedangkan pada kelompok intervensi terjadi penurunan sebanyak 2,9 poin yaitu dari 4,5 menjadi 1,6. Tekanan sistolik, diastolikpun mengalami penurunan baik pada kelompok kontrol maupun intervensi, tetapi kelompok intervensi penurunannya lebih besar dibanding kontrol.

\section{Pengaruh Massage Terhadap Nyeri dan Tekanan Darah Responden}

Tabel 3

Pengaruh Massage terhadap Skala Nyeri dan Tekanan Darah Responden di R. IW Bedah RSJPD Harapan Kita

\begin{tabular}{|c|c|c|c|c|c|c|}
\hline Variabel & Kelompok & $\mathrm{N}$ & Mean & SD & SE & P-Value \\
\hline \multirow{7}{*}{ Skala nyeri } & & & & & & \multirow{4}{*}{$0,015^{*}$} \\
\hline & Kontrol & & & & & \\
\hline & Sebelum & 10 & 5,1 & 0,876 & 0,277 & \\
\hline & Setelah & 10 & 4,6 & 1,075 & 0,340 & \\
\hline & Intervensi & & & & & \multirow{3}{*}{$0,000^{*}$} \\
\hline & Sebelum & 10 & 4,5 & 1,179 & 0,373 & \\
\hline & Setelah & 10 & 1,6 & 1,578 & 0,499 & \\
\hline \multirow{6}{*}{$\begin{array}{c}\text { Tekanan } \\
\text { Darah } \\
\text { Sistolik }\end{array}$} & Kontrol & & & & & \multirow{3}{*}{0,009} \\
\hline & Sebelum & 10 & 124,3 & 11,58 & 3,661 & \\
\hline & Setelah & 10 & 123 & 12,07 & 3,815 & \\
\hline & Intervensi & & & & & \multirow{3}{*}{$0,001^{*}$} \\
\hline & Sebelum & 10 & 117,2 & 6,75 & 2,133 & \\
\hline & Setelah & 10 & 109,9 & 3,45 & 1,090 & \\
\hline Tekanan & Kontrol & & & & & $0,024^{*}$ \\
\hline
\end{tabular}




\begin{tabular}{ccccccc}
\hline Darah & Sebelum & 10 & 80,90 & 9,315 & 2,946 & \\
& Setelah & 10 & 80,30 & 9,262 & 2,929 & \\
\cline { 2 - 7 } & Intervensi & & & & & \multirow{2}{*}{$0,015^{*}$} \\
& Sebelum & 10 & 77,6 & 8,62 & 2,725 & \\
& Setelah & 10 & 74 & 8,60 & 2,720 & \\
\hline
\end{tabular}

*: bermakna pada $\alpha=0,05$

Berdasarkan tabel di atas didapatkan hasil bahwa $p$ kelompok kontrol sebelum diberikan relaksasi rata-rata skor skala nyerinya sebesar 5,1 dengan $S D=0,876$. Setelah diberikan relaksasi didapatkan hasil rata-rata skor nyeri sebesar 4,6 dengan SD $=1,075$. Hal ini menunjukkan bahwa pada kelompok kontrol setelah dilakukan pengujian dengan menggunakan uji $t$ dependen terdapat penurunan skor nyeri yang signifikan dengan nilai $p=0,015(p$ value $<\alpha=0,005$ ) dengan rata-rata penurunan skala nyeri sebesar 0,4.Pada kelompok intervensi didapatkan data ratarata skor nyeri sebelum diberikan massage sebesar 4,5 dengan SD = 1,179 dan setelah diberikan massage rata-rata skor nyeri responden sebesar 1,6 dengan SD = 1,578. Dari hasil pengujian dengan menggunakan uji $t$-dependen didapatkan hasil signifikan dengan nilai $p=0,000(p$ value $\alpha=0,05$ ) dengan rata-rata penurunan skor nyeri sebesar 2,9 poin yaitu dari 4,5 menjadi 1,6. Dari semua hasil pengujian tersebut menunjukkan bahwa penurunan skore nyeri pada kelompok intervensi $(p=0,000 ; \alpha=0,05)$ lebih tinggi bermakna dibandingkan dengan skore nyeri pada kelompok kontrol $(p=0,015 ; \alpha=$ $0,05)$. Bila dilihat secara klinis pada kelompok kontrol rata-rata skor nyeri mengalami penurunan, dan penurunan tersebut lebih besar pada kelompok intervensi. Hal ini menunjukkan pula bahwa penurunan skore nyeri yang terjadi pada kelompok intervensi jauh lebih besar dibandingkan dengan kelompok kontrol.

Tekanan darah sistolik pada kelompok kontrol sebelum diberikan relaksasi ratarata sebesar 124,3 dengan $S D=11,58$. Setelah diberikan relaksasi didapatkan hasil rata-rata tekanan sistolik sebesar 123 dengan SD $=12,07$. Hal ini menunjukkan bahwa pada kelompok kontrol setelah dilakukan pengujian dengan menggunakan uji $t$-dependen terdapat penurunan tekanan sistolik yang signifikan dengan nilai $p=0,009$ ( $p$ value $\alpha=0,005)$. Sedangkan pada kelompok intervensi ratarata tekanan sistolik sebelum diberikan massage sebesar 117,2 dengan SD = 11,58 dan setelah diberikan massage ratarata tekanan darah sistolik responden 109,9 dengan $S D=12,07$. Dari semua hasil pengujian tersebut menunjukkan bahwa penurunan tekanan sistolik sebesar 1,3 pada kelompok intervensi $(p=0,001 ; \alpha=$ 0,05 ) lebih bermakna dibandingkan dengan penurunan tekanan sistolik pada kelompok kontrol $(p=0,009 ; \alpha=0,05)$.

Tekanan darah diastolik responden pada kelompok kontrol sebelum diberikan relaksasi rata-rata sebesar 80,90 dengan $\mathrm{SD}=9,315$. Setelah diberikan relaksasi rata-rata tekanan diastolik menunjukan penurunan menjadi 80,30dengan $\mathrm{SD}=$ 9,262 , setelah dilakukan pengujian dengan menggunakan uji $t$-dependen menunjukkan tidak terdapat penurunan tekanan diastolik yang signifikan dengan nilai $p=0,024(p$ value $>\quad \alpha=0,005)$. Sedangkan pada kelompok intervensi tekanan diastolik sebelum diberikan massage sebesar 77,6 dengan $S D=8,62$ dan setelah diberikan massage rata-rata tekanan diastolik responden sebesar 74dengan SD $=8,60$. Dari hasil pengujian dengan menggunakan uji $t$-dependen didapatkan hasil signifikan dengan nilai $p=0,015$ ( $p$ value $\alpha=0,05$ ). Massage mempunyai hubungan terhadap penurunan tekanan diastolik pada kelompok intervensi $(p=0,001 ; \alpha=0,05)$ sedangkan pada kelompokkontrol tidak bermakna $(p=0,024 ; \alpha=0,05$. 


\section{Perubahan Mean Sebelum dan Setelah Massage}

Tabel 5.4

Perubahan Mean Skala Nyeri dan Tekanan Darah

Sebelum dan Setelah Swedish Massage di R. IW Bedah RSJPD Harapan Kita

\begin{tabular}{lcc}
\hline \multirow{2}{*}{ Variabel } & \multicolumn{2}{c}{ Perubahan Mean } \\
\cline { 2 - 3 } & Kontrol & Intervensi \\
\hline Perubahanmean skala nyeri & 0,5 & 3 \\
Perubahan mean tekanan sistolik & 1,3 & 7,3 \\
Perubahanmean tekanan diastolik & 0,6 & 3,6 \\
\hline
\end{tabular}

Dari tabel di atas dapat diketahui bahwa penurunan skala nyeri dan tekanan darah

\section{PEMBAHASAN}

\section{Data Demografi Responden}

Sebagian besar responden pada kelompok intervensi maupun kontrol berjenis kelamin laki-laki, dengan usia rata-rata pada kelompok intervensi 58,7 tahun dan rata-rata pada kelompok kontrol 56,6 tahun. Hal ini sesuai dengan hasil studi bahwa semakin meningkat usia maka resiko terkena penyakit jantung koroner akan meningkat, terutama pada usia di atas 40 tahun, 4 dari 5 orang yang menderita penyakit lebih dari 65 tahun (Black \& Hawks, 2009). Kaitannya dengan nyeri sebuah studi juga menjelaskan bahwa lansia yang berusia di atas 60 tahun akan berespon lebih sedikit dibandingkan orang muda (Smeltzer, et al., 2010).

\section{Pengaruh Massage terhadap Nyeri}

Hasil EBNP menunjukkan Swedish massage memberikan hasil yang signifikan terhadap penurunan rasanya nyeri pasien bahkan ada beberapa pasien setelah diberikan massage tertidur. Massage adalah stimulasi kutaneus tubuh secara umum, sering dipusatkan pada punggung dan bahu. Massage tidak secara spesifik menstimulasi reseptor tidak nyeri pada bagian reseptor yang sama seperti reseptor nyeri tetapi dapat mempunyai dampak melalui sistem kontrol desenden. Massage dapat membuat pada kelompok intervensi lebih besar dibandingkan dengan kelompok kontrol.

Pada awalnya PJK sering terjadi pada laki-laki, namun pada tahun 1999 angka kejadian PJK pada perempuan cenderung sama setelah mengalami menopause. Wanita yang menggunakan kontrasepsi oral juga memiliki kecenderungan mengalami peningkatan risiko PJK (Black \& Hawks, 2009).

Diagnosa medis pada kelompok intervensi sebagian besar adalah post CABG 3 VD (60\%), begitu juga pada kelompok kontrol (80\%), sedangkan katup repair pada kelompok intervensi $30 \%$ dan pada kelompok kontrol $10 \%$, dengan katup replacement pada kelompok intervensi $10 \%$ dan kelompok kontrol 10\%. Tidak ada responden yang mengalami operasi ulang.

pasien lebih nyaman karena massage membuat relaksasi otot (Smeltzer \& Bare, 2010).

Hasil penerapan EBNP ini mendukung hasil penerapan EBNP sebelumnya yang dilakukan oleh Maulana (2013) bahwa massage secara sangat signifikan efektif menurunkan nyeri pada pasien post CABG. Hal ini sesuai juga dengan hasil penelitian Dion, Rodgers, Cutshall, et all (2011), bahwa terapi massage sebagai manajemen nyeri pelengkap dari terapi farmakologi. Pasien pre dan post tindakan dievaluasi skala nyerinya dengan menggunakan VRS skala 0 - 
10. Dion, Rodgers, Cutshall, et all (2011) juga menjelaskan tidak ada kontraindikasi untuk pasien yang menerima pijitan, tetapi perawat tidak boleh memijit 2 inchi dari luka operasi. Kedalaman dan tekanan pijitan dari mulai ringan sampai sedang. Swedish Massage pada area kepala, lehar, bahu, punggung, tangan atau kaki tergantung keadaan pasien.

Hasil penerapan EBNP sesuai dengan hasil penelitian yang dilakukan oleh Dion et all (2011) bahwa pasien yang menerima pijatan mengalami penurunan nyeri yang signifikan, pada saat pre tindakan rata-rata nyeri responden adalah 5,58 dan setelah tindakan rata-rata nyeri responden turun menjadi rata-rata 2,09 dengan nilai $p<0,001$ dan ada beberapa pasien yang tertidur pada akhir pijitan. Nyeri pada pasien post operasi perlu mendapat perhatian dari perawat karena nyeri dapat memberikan efek yang membahayakan bila tidak segera ditangani, yaitu berupa gangguan sistem pulmonari, kardiovaskular, gastrointestianal, endokrin dan imunologi. Gangguan tersebut dapat berupa meningkatnya laju metabolisme dan curah jantung, kerusakan respon insulin, peningkatan produksi kortisol, dan meningkatnya retensi cairan. Respon stres dapat meningkatkan risiko pasien mengalami gangguan fisiologis misalnya miokard infark, infeksi pulmonar, tromboembolisme dan paralitik ileus yang lama (Smeltzer \& Bare, 2010).

Hasil EBNP juga menunjukkan efektif untuk menurunkan tekanan darah. Perubahan tekanan darah sistol sebelum dan setelah dilakukan Swedish massage pada kelompok intervensi adalah 7,3 lebih besar

\section{SIMPULAN DAN SARAN}

1. Simpulan

a. Rata-rata umur renponden berumur 56,6 tahun pada kelompok kontrol dan 5,1 tahun pada kelompok intervensi. Rata-rata Ejection Fraction (EF) responden 60,4 dibanding pada kelompok kontrol, begitu juga tekanan darah diastolik. Hasil EBNP ini juga sesuai dengan hasil penelitian Braun, Stanguts, Casanelia, et all (2012) tentang efek massage terhadap penurunan kecemasan, nyeri, ketegangan otot dan relaksasi pasien yang dalam hal ini diukur dengan indicator tekanan darah, frekuensi nadi, frekuensi nafas dan kepuasan pasien. Hasil penelitiannya menunjukkan setelah diberikan terapi pijatan tingkatan nyeri pasien menurun secara signifikan $(\mathrm{p}=$ $0,001)$, kecemasan menurun ( $p<$ $0,0001)$, ketegangan otot $(p=0,002)$, relaksasi meningkat $(p<0,0001)$ dan tingkat kepuasan $(p=0,016)$. Nyeri secara signifikan menurun setelah mendapat terapi pijatan pada hari kedua atau ketiga post operasi. Pada kelompok kontrol tidak ada perubahan yang signifikan. Kesimpulan akhir pada penelitian ini bahwa terapi pijatan secara signifikan mengurangi nyeri, kecemasan, ketegangan otot, meningkatkan relaksasi dan kepuasan setelah bedah jantung.

Penurunan tekanan darah pada pasien ini berhubungan dengan efek relaksasi pasien. Nyeri dan tekanan darah sangat erat kaitannya yaitu nyeri apabila tidak ditangani akan meningkatkan aktifitas syaraf simpatis, sistem saraf otonom dirangsang dan melepaskan epinefrin yang meningkatkan tekanan darah dan nadi sehingga dapat meningkatkan beban kerja miokardium dan pasokan oksigen ke jantung, sehingga akan meningkatkan Leng of Stay (LoS) pasien dan angka mortalitas akan meningkatkan (Arbour \& Gelinas, 2011).

pada kelompok kontrol dan 61,3 pada kelompok intervensi.

b. Rata-rata tingkat nyeri pada kelompok control sebelum dilakukan relaksasi sebesar 5,1, setelah diberikan relaksasi menurun manjadi 4,5 dengan nilai $p=0,015(p$ value $\alpha=0,005)$ 
dengan rata-rata penurunan skala nyeri sebesar 0,4. Rata-rata tingkat nyeri pada kelompok intervensi sebelum diberikan Swedish massage dan relaksasi adalah 4,5, setelah diberikan tindakan intervensi rata-rata tingkat nyeri responden menjadi 1,6 . Hasil pengujian $p=0,000$ ( $p$ value $<\alpha=0,05$ ).

C. Perubahan nilai mean skala nyeri dan penurunan tekanan darah lebih besar pada kelompok intervensi, disbanding kelompok kontrol perubahan nilai tekanan darah sistolik, tekanan darah diastolik pada kelompok intervensi lebih besar dibandingkan dengan kelompok intervensi.

\section{SARAN}

a. Swedish Massage sebaiknya dijadikan sebagai salah satu intervensi keperawatan dalam menangani masalah pasien kardiovaskular.

b. Perlu dilakukan penelian lebih lanjut tentang efektifitas Swedish massage dikombinasikan dengan terapi lainnya terhadap pasien dengan gangguan kardiovaskular.

c. Dipertimbangkan untuk menambah sample penelitian bila akan melakukan penelitian yang sama.

\section{DAFTAR PUSTAKA}

Arbour, C. \& Gelinas, C. (2011). Setting goal for pain management when using a behavioral scale: example with the Critical Care Pain Observation Tools. Critical Care Nurse Journal. American Association of Critical Care Nurse, Vol.31, No. 6.

Braun,L.A., Stanguts, C., Casanelia, L., et all. (2012). Massage therapy for cardiac surgery patients - a randomized trial. $J$. Thorac Cardiovascular Surgery, Vol. 144(6): 1453

Black, J.M. \& Hawks, J.H. (2009). Medical Surgical Nursing: Clinical Management for Positive Outcomes. Eighth Edition. Volume 2. USA : Saunders Elsevier.

Gelinas, C., Fillion, L., Puntillo, K.A., Viens, C. \& Fortier, M. (2006). Validation of the Critical Care Pain Observation Tool in Adult Patients. Critical Care Nurse Journal. American Association of Critical Care Nurse, Vol.15, No. 4, Februari 2006.

Guyton \& Hall (2010). Buju Ajar Fisiologi Kedokteran. Ed 11. Jakarta: Penerbit Buku Kedokteran EGC. 
Ignativius, D.D., \& Workman, M.L.(2006). Medical-Surgical Nursing : Critical Thingking For Collaborative Care. (4th Ed), St. Louis, Missouri Elsevier Saunders.

Kabes, A.M., Graves, J.K. \& Norris, J. (2013). Further validation of the nonverbal pain scale in Intensive Care Patients. Critical Care Nurse Journal. American Association of Critical Care Nurse, Vol.29, No. 1, Februari 2009.

Nerbass, Feltrim, Souza, et all (2010). Effects of massage therapy on sleep quality after Coronary Arteri Bypass Graft surgery. Clinic, 65(11): 1105-1110.

Maulana, I. (2013). Analisis praktek residensi keperawatan medikal bedah pada psien dengan gangguan kardiovaskular dengan penerapan model konservasi myra E. Levine di RS Pusat Jantung dan Pembuluh Darah

Stites, M. (2013). Observational Pain Scale in Critical III Adults. Critical Care Nurse Journal. American Association of Critical Care Nurse, Vol.3, No. 6, Juni 2013.
Harapan Kita. Jakarta: Universitas Indonesia.

Perry, A.G \& Potter, P.A (2007). Basic Nursing. (6rd Ed). St.Louis: Mosby Elsevier.

Rokhaeni, et al., (2001). Buku Ajar Keperawatan Kardiovaskular. Edisi Pertama. Jakarta: Bidang Diklat Pusat Kesehatan Jantung \& Pembuluh Darah Nasional Harapan Kita.

Schanffner, N., Folkers, G., Kappeli, S., Musholt, M., Hofbauer, G.G. (2012). A new tool for real time pain Assessment in experimental and clinical environments. Plos one, Vol 7, issue 11, e51014, Nov 2012.

Soetisna TW. (2013). Rumah Sakit Harapan Kita layani 3000 pasien/tahun. Jakarta. Suara Pembaruan. www.suarapembaruan.com

Smeltzer, S.C \& Bare, B.G. (2010). Textbook of medical surgical nursing. Philadelphia: Lippincot Williams \& Wilkins. 